\title{
DNA fragmentation, an indicator of apoptosis, in cultured black tiger shrimp Penaeus monodon infected with white spot syndrome virus (WSSV)
}

\author{
Abeer H. Sahtout*, M. D. Hassan, M. Shariff \\ Aquatic Animal Health Unit, Faculty of Veterinary Medicine, Universiti Putra Malaysia, 43400 Serdang, Selangor, Malaysia
}

ABSTRACT: Fifty black tiger shrimp Penaeus monodon from commercial cultivation ponds in Malaysia were examined by Tdt-mediated dUTP nick-end labeling (TUNEL) fluorescence assay and agarose gel electrophoresis of DNA extracts for evidence of DNA fragmentation as an indicator of apoptosis. From these specimens, 30 were grossly normal and 20 showed gross signs of white spot syndrome virus (WSSV) infection. Of the 30 grossly normal shrimp, 5 specimens were found to be positive for WSSV infection by normal histology and by nested polymerase chain reaction (PCR) analysis. All of the specimens showing gross signs of WSSV infection were positive for WSSV by normal histology, while 5 were positive by nested PCR only (indicating light infections) and 15 were positive by 1-step PCR (indicating heavy infections). Typical histological signs of WSSV infection included nuclear hypertrophy, chromatin condensation and margination. None of the 25 grossly normal shrimp negative for WSSV by 1-step PCR showed any signs of DNA fragmentation by TUNEL assay or agarose gel electrophoresis of DNA extracts. The 10 specimens that gave PCR-positive results for WSSV by nested PCR only (i.e., 5 grossly normal shrimp and 5 grossly positive for WSSV) gave mean counts of $16 \pm 8 \%$ TUNEL-positive cells, while the 25 specimens PCR positive by 1-step PCR gave mean counts of $40 \pm 7 \%$ TUNEL-positive cells. Thus, the number of TUNEL positive cells present in tissues increased with increasing severity of infection, as determined by gross signs of white spots on the cuticle, the number of intranuclear inclusions in histological sections, and results from single and nested PCR assays. DNA extracts of PCR-positive specimens tested by agarose gel electrophoresis showed indications of DNA fragmentation either as smears or as 200 bp ladders. Given that DNA fragmentation is generally considered to be a hallmark of apoptosis, the results suggested that apoptosis might be implicated in shrimp death caused by WSSV.

KEY WORDS: Apoptosis · White spot syndrome virus · WSSV · Penaeus monodon

Resale or republication not permitted without written consent of the publisher

*E-mail: abehas@hotmail.com
Apoptosis is the process of programmed cell death (Clem et al. 1996), and is now widely recognized as being vital to a diversity of biological processes such as metamorphosis, embryonic morphogenesis and hormone-induced tissue remodelling (Fesus et al. 1991). It is also a major defense mechanism of the vertebrate body for removal of unwanted and potentially dangerous cells such as virus-infected and tumor cells (Wyllie et al. 1980, Wyllie 1981). The full implications of this biological process for controlling the normal loss of cells have only recently been recognized (Fesus et al. 1991). Programmed cell death also occurs in insect development and tissue homeostasis, although chromatin digestion (a biochemical hallmark of apoptosis) has not been documented in invertebrate-programmed cell death (Clem et al. 1991).

It has been suggested that apoptosis may be the cause of death in shrimp with lethal viral infections and that it may be an integral part of a process for adaptive tolerance to viruses in crustaceans (Flegel 1997, Pasharawipas et al. 1997). The idea of tolerance subsequently led to the proposal that crustaceans respond to viral pathogens by using a mechanism of adaptive accommodation (Flegel \& Pasharawipas 1998). The present work was carried out to test a prediction of the adaptive accommodation theory that shrimp dying from viral infections expire from massive cellular apoptosis of viral-infected cells.

The virus chosen for the study was white spot syndrome virus (WSSV). Since 1994, it has caused mass mortality among cultured penaeid shrimp throughout Asia (Flegel 1997, Flegel et al. 1997). It was first described as a rod-shaped, non-occluded baculo-type virus (Takahashi et al. 1994, Wongteerasypaya et al. 1995), but it is now regarded as an unclassified virus of uncertain affinity (Kasornchandra et al. 1998). This 
report presents the first evidence indicating that apoptosis may be implicated in the death of black tiger shrimp Penaeus monodon severely infected with WSSV.

Materials and methods. Thirty grossly normal shrimp and 20 shrimp with gross signs of WSSV were collected from July to September 1997 from farms located along the West Coast of Peninsular Malaysia. Genomic DNA was extracted immediately from gill, stomach, abdomen and muscle tissue using DNAzol reagent, diluted with TE buffers (10 mM Tris, $1 \mathrm{mM}$ EDTA, and $\mathrm{pH}$ 7.6) and then stored at $-20^{\circ} \mathrm{C}$ until used. The live shrimp were then processed for study by light microscopy. Gill, stomach, abdominal and muscle tissues were fixed with Davidson's fixative for $24 \mathrm{~h}$, and transferred to $50 \%$ ethyl alcohol until used. These samples were processed and sectioned following paraffin embedding using the methods described by Bell \& Lightner (1988). Half of the sections were stained with haematoxylin and eosin (H\&E) and then examined by light microscopy for histopathology typical of WSSV infections (Wongteerasupaya et al. 1995, Lightner 1996). The remaining sections were stained with an apoptosis detection kit (Apoptosis detection system, fluorescein from Promega) based on TdT-mediated dUTP nick-end labeling (TUNEL) analysis. After staining as directed by the kit manufacturer, a mounting reagent (Fluoro Guard Antifade, BioRad) was added to act as an antifade to slow photobleaching. Slides of tissue sections were examined using a fluorescence microscope where nuclei of apoptotic cells gave a green fluorescence as opposed to red fluorescence for normal nuclei. To determine the proportion of TUNELpositive and -negative cells, 100 cells were counted using a battlement method from randomly selected sections of various organs.

DNA extracts from various organs were used as templates for nested polymerase chain reaction (PCR) detection of WSSV infection using Taiwanese designed primers (Lo et al. 1996) and a Rapidcycler (Idaho Technology). Positive and negative controls were also run to avoid any false positive PCR results. The positive controls consisted of DNA extracts from shrimp with gross signs of WSSV infection and with typical WSSV intranuclear inclusions by histological examination. Autoclaved, deionized, double distilled water $\left(\mathrm{DDDH}_{2} \mathrm{O}\right)$ was used as the negative control. Samples were subjected to 1- and 2-step (nested) PCR analysis and amplicons were detected by agarose gel electrophoresis as described below. For detection of DNA ladders considered characteristic of DNA fragmentation in apoptotic cells, the same DNA extracts were run in $2 \%$ agarose gels (type 1:low EEO Sigma) using a $10 \mu \mathrm{l}$ volume for each sample with $1 \times$ TBE running buffer (54 $\mathrm{g} \mathrm{m} \mathrm{l}^{-1}$ TRIS base, $27.5 \mathrm{~g} \mathrm{~m} \mathrm{l}^{-1}$ Boric acid and $20 \mathrm{ml}$ EDTA, pH 8.0). Electrophoresis was carried out at $135 \mathrm{~V}$ for $1 \mathrm{~h}$ together with $\lambda$ HindIII markers and the gel was then stained in ethidium bromide to visualize nucleic acid bands using ultraviolet light.

Results and discussion. According to Wongteerasupaya et al. (1995), Lightner (1996), Wang et al. (1997, 1999) and Mohan et al. (1998) WSSV is found in most tissues or organs of ectodermal and mesodermal origin. These include the subcuticular epithelium, gills, lymphoid organ, antenal gland, hematopoietic tissue, connective tissue, ovary, and the ventral nerve cord. Most of these studies were done by light microscopy. They demonstrated degenerated cells in various tissues characterized by hypertrophied nuclei with basophilic inclusions. Chromatin was gradually marginated followed by nuclear dissociation (Wang et al. 1999). In the present study, all the shrimp with gross signs of WSSV showed similar histopathological findings as those previously described (Fig. 1D). Affected cells were found in most organs and tissues of ectodermal and mesodermal origin.

The grossly healthy shrimp studied (30) were all negative for WSSV by 1-step PCR assay but 5 (17\%) were positive by nested PCR (Table 1). The 25 $(87 \%)$ negative for WSSV by nested PCR showed no TUNEL-positive cells (Fig. 1A), while the 5 positive by nested PCR had low numbers of TUNEL-positive cells (Fig. 1B). The need to carry out nested PCR to detect WSSV indicated a low level of viral DNA template in the extract and this, in turn, suggested that the shrimp specimens were at an early stage of infection. Of the 20 shrimp with gross signs of WSSV infection, 15 (75\%) were positive for WSSV by 1-step PCR assay, and 5 (25\%) by nested PCR assay. Histological examination

Table 1. Results of PCR tests for WSSV, histological assays, TUNEL assays and agarose gel tests for DNA ladders from specimens of grossly normal shrimp and shrimp showing gross signs of WSSV infection

\begin{tabular}{|lcccccc|}
\hline Shrimp group & $\begin{array}{c}\text { WSSV-positive } \\
\text { by histology }\end{array}$ & $\begin{array}{c}\text { WSSV-positive } \\
\text { by 1-step PCR }\end{array}$ & $\begin{array}{c}\text { WSSV-positive } \\
\text { by nested PCR }\end{array}$ & $\begin{array}{c}\text { WSSV-negative } \\
\text { by nested PCR }\end{array}$ & $\begin{array}{c}\text { High no. TUNEL- } \\
\text { positive cells }\end{array}$ & $\begin{array}{c}\text { DNA } \\
\text { ladders }\end{array}$ \\
\hline $\begin{array}{l}\text { Grossly normal }(\mathrm{n}=30) \\
\begin{array}{l}\text { Gross signs of WSSV } \\
\text { infection }(\mathrm{n}=20)\end{array}\end{array}$ & 3 & 0 & 5 & 25 & No & No \\
\hline
\end{tabular}




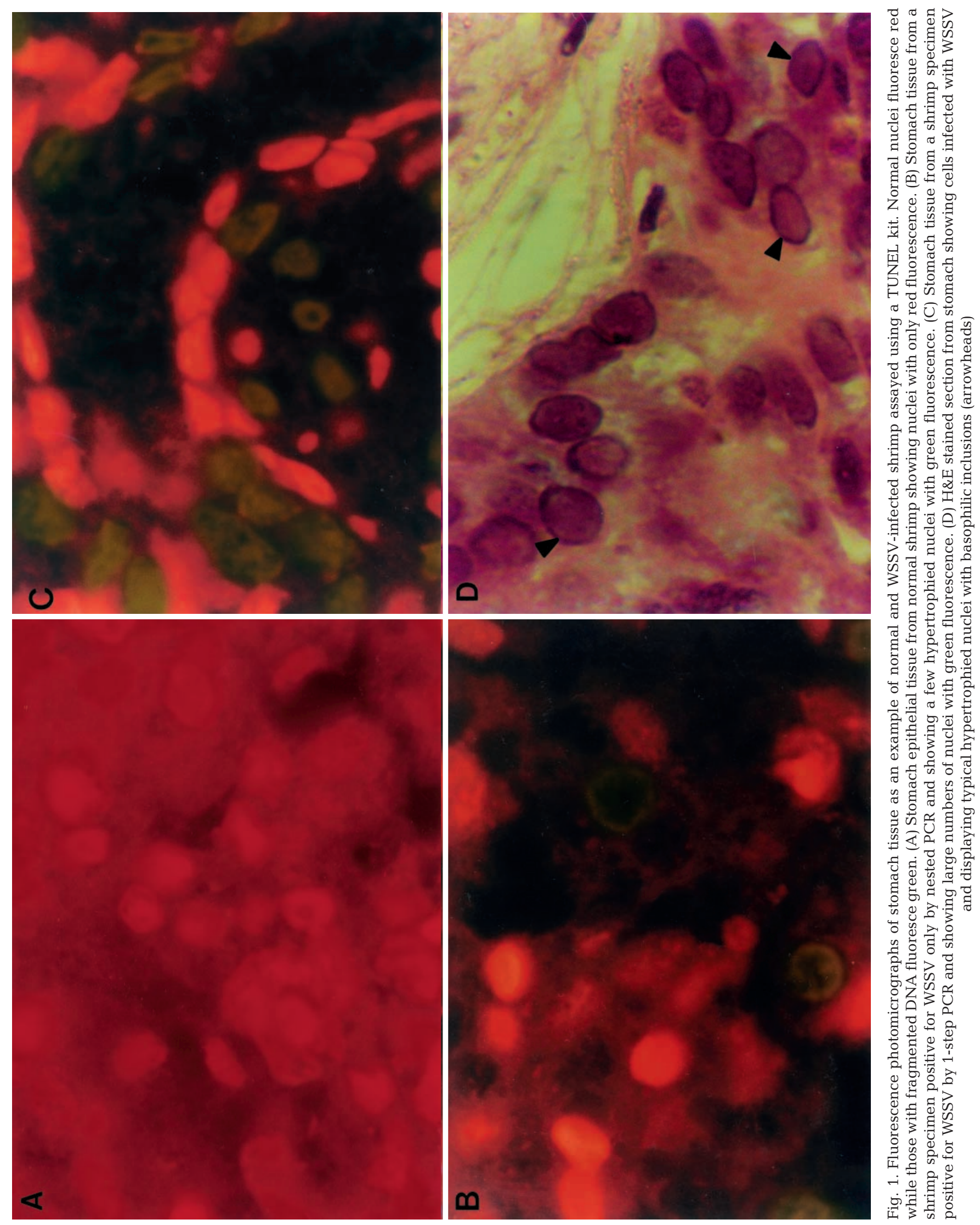


Table 2. Mean counts of TUNEL-positive cells in shrimp positive for WSSV by 1-step or nested PCR assay. Note: means were all significantly different $(\mathrm{p}<0.05)$

\begin{tabular}{|lc|}
\hline PCR test result group & $\begin{array}{c}\text { Mean TUNEL-positive } \\
\text { cell count }(\%)\end{array}$ \\
\hline Negative by nested PCR $(\mathrm{n}=25)$ & 0.0 \\
Positive by nested PCR only $(\mathrm{n}=10)$ & $16 \pm 8$ \\
Positive by 1-step PCR $(\mathrm{n}=15)$ & $40 \pm 7$ \\
\hline
\end{tabular}

by light microscopy revealed intranuclear inclusions typical of WSSV in sections of all 20 (Fig. 1D). The 10 grossly healthy shrimp or grossly WSSV-positive shrimp that gave PCR-positive results for WSSV infection by nested PCR assay only (i.e., early stage infections) gave a mean TUNEL-positive cell count of $16 \pm$ $8 \%$ (Table 2, Fig. 1B). By contrast, specimens with gross signs of WSSV infection and positive for WSSV by 1-step PCR gave a mean TUNEL-positive cell count of $40 \pm 7 \%$ (Table 2, Fig. 1C). A 1-way ANOVA test revealed that the results for all groups were significantly different $(\mathrm{p}<0.05)$. Thus, mean TUNEL-positive cell counts increased with increasing severity of infection. In addition, TUNEL counts of 100 cells from randomly selected fields of stomach, gill, hepatopancreatic, abdominal and muscle tissue were made for each shrimp. The highest TUNEL-positive count was from the abdominal epithelium followed by the stomach epithelium, hepatopancreatic interstitial cells, gills and muscles (Table 3).

Although the TUNEL assay for DNA fragmentation detection has not been established as a routine assay for apoptosis in crustaceans, it is widely applied in other animals as an indicator of apoptosis (Walker et al. 1993). The results obtained here suggest that the TUNEL assay may also be an indicator of apoptosis in crustaceans. Indeed, Anggraeni \& Owens (2000), in another study, have used TUNEL-positive staining as evidence for apoptosis in lymphoid organ cells of Penaeus monodon infected with a virus.

Further support for DNA fragmentation was obtained by agarose gel electrophoresis of DNA extracts from WSSV-infected shrimp. DNA samples from

Table 3. Mean TUNEL-positive cell counts in organs of WSSVinfected shrimp that tested positive for WSSV by 1-step PCR

\begin{tabular}{|lc|}
\hline Organs & Mean TUNEL-positive cell count \\
\hline Abdominal epithelium & $46 \pm 7$ \\
Gills & $28 \pm 5$ \\
Hepatopancreas & $30 \pm 5$ \\
Muscle & $15 \pm 6$ \\
Stomach & $38 \pm 7$ \\
\hline
\end{tabular}

shrimp that were either 1-step or nested PCR-positive for WSSV showed either continuous DNA smears or ladders (Fig. 2). The most obvious DNA fragmentation was observed in heavily infected shrimp. It was less frequently detected at early stages of infection. No DNA fragmentation was found in WSSV-PCR negative samples. The DNA migrated as discrete bands, which, by comparison to DNA markers, gave a ladder of approximately 200 base pair (bp) steps. Such DNA ladders are considered to be a hallmark of apoptosis, although continuous smears may also indicate DNA fragmentation due to apoptosis (Walker et al. 1993). The ladders result from DNA fragmentation catalyzed by an endogenous endonuclease that cleaves internucleosomal DNA to form ladder-like bands of oligonucleosome fragments separated by approximately 200 bp (Wyllie et al. 1980, Kokileva 1989). Such a pattern is not characteristic of WSSV viral DNA (Wongteerasupaya et al. 1995), and it suggested that the TUNEL-staining reaction did arise as a result of shrimp DNA fragmentation.

Although the Promega TUNEL kit was designed for studying apoptosis in mammalian cells, it appears that it may be used successfully for the detection of DNA fragmentation in crustaceans as well. However, absolute proof that DNA fragmentation is also a marker for apoptosis in crustaceans, as in other animals, must await the verification of molecular events associated with apoptosis, and particularly the upregulation or activation of the required endogenous endonuclease.

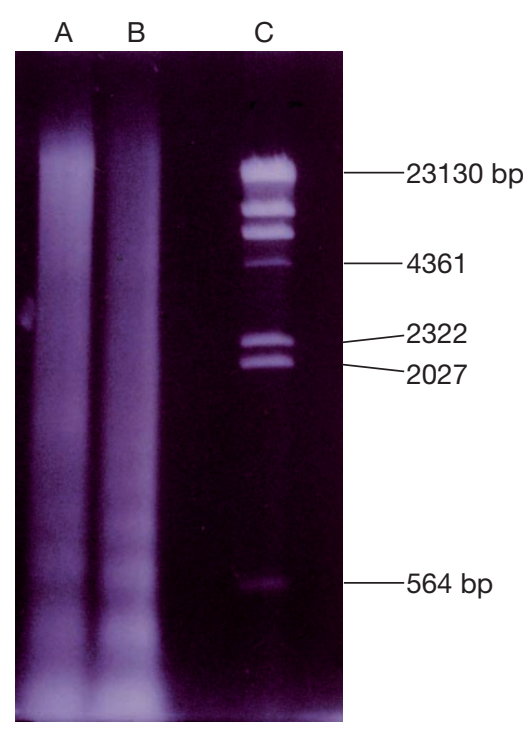

Fig. 2. DNA laddering from shrimp samples that gave positive reactions for WSSV by PCR testing. A: WSSV-positive by nested PCR; $\mathrm{B}$ : WSSV-positive by 1 -step PCR $;$ C: $\lambda$ HindIII marker 
The results presented here give some support to the prediction of the viral accommodation theory of Flegel \& Pasharawipas (1998) that shrimp dying of viral infection will show evidence of cell death by apoptosis. That theory was formulated to explain the common occurrence of persistent viral infection in shrimp. According to the theory, apoptosis results when an active shrimp mechanism to accommodate viral pathogens fails. On the other hand, it might be argued that viral infections would normally cause apoptosis unless blocked by specific inhibition of apoptosis (IAP) genes. These occur in some insect baculoviruses (Clem et al. 1991), where the mechanism of the apoptosis block can differ with viral type or stain. More studies are required to determine whether WSSV possesses a similar IAP gene(s) and whether it might trigger apoptosis at some point during infection.

Acknowledgements. The authors are grateful to Mr Hayder Hasan Al Sahtout for providing the shrimp samples and Mr Nasir Tsafe Umar for his valuable comments on the manuscript.

\section{LITERATURE CITED}

Anggraeni MS, Owens L (2000) The haemocytic origin of lymphoide organ spheroid cell In the penaeid prawn Penaeus monodon. Dis Aquat Org 40:85-92

Bell TA, Lightner DV (1988) A handbook of normal penaeid shrimp histology. World Aquaculture Society, Baton Rouge, LA

Clem RJ, Fechheimer M, Miller LK (1991) Prevention of apoptosis by a baculovirus gene during infection of insect cells. Science 254:1388-1390

Clem RJ, Hardwick JM, Miller LK (1996) Anti-apoptotic genes of baculoviruses. Cell Death Differ 3:9-16

Fesus LP, Davies JA, Piacentini M (1991) Apoptosis: molecular mechanisms in programmed cell death. Eur J Cell Biol $56: 170-177$

Flegel TW (1997) Special topic review: major viral diseases of the black tiger prawn (Penaeus monodon) in Thailand. World J Microbiol Biotechnol 13:433-442

Flegel TW, Pasharawipas T (1998) Viral accommodation: a new concept for crustacean response to viral pathogens. In: Flegel TW (ed) Advances in shrimp biotechnology. National Center for Genetic Engineering and Biotechnology, Bangkok, p 245-250

Flegel TW, Boonyaratpalin S, Withyachumnarnkul B (1997) Current status of research on yellow-head virus and white-spot virus in Thailand. In: Flegel TW, MacRae IH (eds) Diseases in Asian aquaculture III. Asian Fisheries Society, Manila, p 285-296
Kasornchandra J, Boonyaratpalin S, Itami T (1998) Detection of white spot syndrome in cultured Penaied shrimp in Asia: microscopic observation and polymerase chain reaction. Aquaculture 164:243-251

Kokileva L (1989) Endogenous degradation of rat liver chromatin studied by agar gel electrophoresis of nuclei. Mol Biol Rep 13:139-143

Lightner DV (1996) A handbook of shrimp pathology and diagnostic procedures for diseases of cultured penaeid shrimp. World Aquaculture Society, Baton Rouge, LA

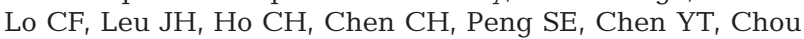
$\mathrm{CM}$, Yeh PY, Huang CJ, Chou HY, Wang $\mathrm{CH}$, Kou GH (1996) Detection of baculovirus associate with white spot syndrome (WSBV) in penaeid shrimp using polymerase chain reaction. Dis Aquat Org 25:33-141

Mohan CV, Shankar KM, Kulkarni S, Sudha PM (1998) Histopathology of cultured shrimp showing gross signs of yellow head syndrome and white spot syndrome during 1994 Indian epizootics. Dis Aquat Org 34:9-12

Pasharawipas T, Flegel TW, Sriurairatana S, Morrison DJ (1997) Latent yellow-head infections in Penaeus monodon and implications regarding disease tolerance or resistance. In: Flegel TW, Menasveta P, Paisarnrat S (eds) Shrimp biotechnology in Thailand. National Center for Genetic Engineering and Biotechnology, Bangkok, p 45-53

Takahashi Y, Itami T, Kondom M, Maeda M, Fujii R, Tomonaga S, Supamattaya K, Boomyaratpalin S (1994) Electron microscopic evidence of bacilliform virus infection in kuruma shrimp (Penaeus japonicus). Fish Pathol 29: $121-125$

Walker PR, Kokileva L, LeBlanc J, Sikorska M (1993) Detection of the initial stages of DNA fragmentation in apoptosis. Biotechniques 15:1032-1040

Wang CS, Tang KFJ, Kou GH, Chen SN (1997) Light and electron microscopic evidence of white spot disease in the giant tiger shrimp, Penaeus monodon (Fabricus), and the kuruma shrimp, Penaeus japonicus (Bate), cultured in Taiwan. J Fish Dis 20:323-331

Wang YG, Hassan MD, Shariff M, Zamri SM, Chen X (1999) Histopathology and cytopathology of white spot syndrome virus (WSSV) in cultured Penaeus monodon from peninsular Malaysia with emphasis on pathogenesis and the mechanism of white spot formation. Dis Aquat Org 39: $1-11$

Wongteerasupaya C, Vickers JE, Sriurairatana S, Nash GL, Akarajamoran A, Boonsaeng V, Panyim S, Tassanakajon A, Withyachumnarnkul B, Flegel TW (1995) A nonoccluded, systemic baculovirus that occurs in cell of ectodermal and mesodermal origin and causes high mortality in the black tiger prawn Penaeus monodon. Dis Aquat Org 21:21-69

Wyllie AH (1981) Cell death: a new classification separating apoptosis from necrosis. In: Bowen ID, Lockshin RA (eds) Cell death in biology and pathology. Chapman and Hall, London

Wyllie AH, Kerr JFR, Currie AR (1980) Cell death: the significance of apoptosis. Int Rev Cytol 68:251-305

Submitted: October 26, 1999; Accepted: November 28, 2000 Proofs received from author(s): January 31, 2001 